\title{
Development of Oral Epithelial Cell Line ROE2 with Differentiation Potential from Transgenic Rats Harboring Temperature-Sensitive Simian Virus 40 Large T-Antigen Gene
}

\author{
Yoshiaki TABUCHI ${ }^{1)}$, Shigehito WADA ${ }^{3)}$, Mika IKEGAME ${ }^{4)}$, Ayako KARIYA ${ }^{5)}$, \\ Yukihiro FURUSAWA ${ }^{5)}$, Nobuhiko HOSHI ${ }^{6}$, Tatsuya YUNOKI ${ }^{5)}$, Nobuo SUZUKI ${ }^{7)}$, \\ Ichiro TAKASAKI ${ }^{1)}$, Takashi KONDO ${ }^{5)}$, and Yoshihisa SUZUKI') \\ 1)Division of Molecular Genetics Research, Life Science Research Center, University of Toyama, 2630 Sugitani, \\ Toyama 930-0194, Japan \\ ${ }^{2)}$ Center for Interdisciplinary Research, Tohoku University, Aramaki aza Aoba 6-3, Aoba-ku, Sendai, Miyagi \\ 980-8578, Japan \\ ${ }^{3}$ Department of Oral and Maxillofacial Surgery, Graduate School of Medicine and Pharmaceutical Sciences, \\ University of Toyama, 2630 Sugitani, Toyama 930-0194, Japan \\ 4) Department of Oral Morphology, Graduate School of Medicine, Dentistry and Pharmaceutical Sciences, Okayama \\ University, 2-5-1 Shikata-cho, Kita-ku, Okayama 700-8525, Japan \\ ${ }^{5)}$ Department of Radiological Sciences, Graduate School of Medicine and Pharmaceutical Sciences, University of \\ Toyama, 2630 Sugitani, Toyama 930-0194, Japan \\ ${ }^{6)}$ Department of Animal Science, Graduate School of Agricultural Science, Kobe University, 1-1 Rokkodai, Nada- \\ ku, Kobe, Hyogo 657-8501, Japan \\ 7) Noto Marine Laboratory, Institute of Nature and Environmental Technology, Kanazawa University, Ogi, Noto-cho, \\ Ishikawa 927-0553, Japan
}

\begin{abstract}
We have developed an immortalized oral epithelial cell line, ROE2, from fetal transgenic rats harboring temperature-sensitive simian virus 40 large T-antigen gene. The cells grew continuously at either a permissive temperature of $33^{\circ} \mathrm{C}$ or an intermediate temperature of $37^{\circ} \mathrm{C}$. At the nonpermissive temperature of $39^{\circ} \mathrm{C}$, on the other hand, growth decreased significantly, and the Sub-G1 phase of the cell cycle increased, indicating that the cells undergo apoptosis at a nonpermissive temperature. Histological and immunocytochemical analyses revealed that ROE2 cells at $37^{\circ} \mathrm{C}$ had a stratified epithelial-like morphology and expressed cytokeratins Krt4 and Krt13, marker proteins for oral nonkeratinized epithelial cells. Global-scale comprehensive microarray analysis, coupled with bioinformatics tools, demonstrated a significant gene network that was obtained from the upregulated genes. The gene network contained 16 genes, including Cdkn1a, Fos, Krt13, and Prdm1, and was associated mainly with the biological process of skin development in the category of biological functions, organ development. These four genes were validated by quantitative real-time polymerase chain reaction, and the results were nearly consistent with the microarray data. It is therefore anticipated that this cell line will be useful as an in vitro model for studies such as physiological functions, as well as for gene expression in oral epithelial cells.
\end{abstract}

Key words: differentiation, gene network, oral epithelial cell, temperature-sensitive simian virus 40 large T-antigen

(Received 26 February 2013 / Accepted 9 July 2013)

Address corresponding: Y. Tabuchi, Division of Molecular Genetics Research, Life Science Research Center, University of Toyama, 2630 Sugitani, 930-0194 Toyama, Japan

(C2014 Japanese Association for Laboratory Animal Science 


\section{Introduction}

Oral epithelial tissues form an important barrier between the tissue and the environment, and they protect against exogenous substances and pathogens. The oral cavity contains two types of stratified epithelia: keratinized epithelia located in the gingival and hard palate tissues, and nonkeratinized epithelia in buccal tissues, the underside of the tongue, and soft palate tissues. To maintain these epithelial barriers, epithelial tissues undergo constant renewal. Oral keratinized and nonkeratinized epithelia are composed of cells that show various differentiated phenotypes, and the progenitor cells in the basal layer give rise to all of the epithelial cell types in the oral epithelia $[32,38]$. Cell junctions including desmosomes function as points in cell-cell and cell-basement membranes, and connect to the keratin cytoskeleton to the cell surface. It is also well known that cytokeratins, important components of cytoskeletons, are reliable indicators of oral epithelial cell differentiation [32, 36-38]. Cytokeratins keratin 5 (Krt5) and Krt14 are expressed in basal cells in both oral keratinized and nonkeratinized epithelia, whereas the keratin pairs Krt1/ $\mathrm{Krt10}$ and $\mathrm{Krt} 4 / \mathrm{Krt} 13$ are found in keratinized and nonkeratinized epithelia, respectively.

The use of in vitro cell culture systems has been of central importance for research into the physiology, pharmacology, and toxicology of cell lines; and such systems function at both the cellular and molecular levels. Primary cell culture methods have been developed for the study of oral epithelial cells $[17,46]$; however, these primary cultures contain multiple cell types with different developmental stages and are frequently invaded by fibroblastic cells. Moreover, the proliferation activity of primary culture cells is limited, and some variability among cultured cells from individual sources has been observed between experiments. On the other hand, it has also been thought that cell lines are a good tool for molecular biology, especially recombinant DNA experiments, because they are a continuous source of readily available cells. Many oral epithelial cell lines have been established from normal cell cultures [18] or carcinoma cells $[19,25]$. However, the genetic backgrounds of these cell lines are undefined and unstable, and usually are lacking some of their normal properties. Immortalization of primary cultures can be achieved directly with viral oncogenes. Either simian virus 40 (SV40) large T-antigen or its mutant temperature-sensi- tive simian virus 40 (tsSV40) large T-antigen can establish continuous proliferation without a transformed phenotype in primary culture cells $[15,16]$. Previous reports demonstrated that the SV40 large T-antigen can stabilize cell-type-specific functions in oral epithelial immortalized cell lines [9, 20]. Moreover, transgenic (TG) mice harboring tsSV40 large T-antigen have been very useful for establishing immortalized cell lines from many kinds of tissues including epithelia [27, 28]. Using TG mice, several kinds of epithelial cell lines with specific functions have been developed from kidney distal tubule [45, 54], gastric fundic mucosa [39], gingival epithelium [12], tracheal epithelium [40], intestinal epithelium [42, 52], and epididymal epithelium [3]. Recently, some groups, including ours, have reported that TG rats bearing the tsSV40 large T-antigen [47] are a good source of conditionally immortalized epithelial cell lines, including gastric fundic mucosal [43], small intestinal [13], and tracheal epithelial cells [44].

The present study was undertaken to establish an oral epithelial cell line to constitute a continuous source of cells readily available for oral epithelial investigations using TG rats harboring the tsSV40 large T-antigen and to characterize these cells' biological functions, including epithelial functions and gene expressions.

\section{Materials and Methods}

Establishment of an oral epithelial cell line and cell culture

TG rats (Wistar strain) which have a tsSV40 large T-antigen gene [pSVtsA58ori (-)-2] [47] were obtained from PhoenixBio Co., Ltd. (Hiroshima, Japan). The experiments were performed according to guidelines presented by the Animal Care and Use Committee of University of Toyama.

Tongues were dissected out from fetal rats (18-dayold). The tissues from underside of tongues were rinsed with phosphate-buffered saline (PBS), and were minced finely with scissors. The minced tissues were incubated in Dulbecco's modified Eagle medium/Ham F-12 (1:1) (DMEM/F12) medium containing $0.1 \%$ collagenase for $30 \mathrm{~min}$ at $37^{\circ} \mathrm{C}$, and epithelial tissues were separated from mesenchyme with the aid of forceps under a dissecting microscope, and cultured in DMEM/F12 medium supplemented with $2 \%$ fetal bovine serum (FBS), $1 \%$ ITES $(2.0 \mathrm{mg} / \mathrm{l}$ insulin, $2.0 \mathrm{mg} / \mathrm{l}$ transferrin, $0.122 \mathrm{mg} / \mathrm{l}$ ethanolamine and $9.14 \mu \mathrm{g} / \mathrm{l}$ sodium selenite), $10 \mathrm{ng} / \mathrm{ml}$ 
epidermal growth factor (EGF), $100 \mathrm{unit} / \mathrm{ml}$ penicillin, $100 \mu \mathrm{g} / \mathrm{ml}$ streptomycin and $2.5 \mu \mathrm{g} / \mathrm{ml}$ amphotericin B in a collagen type I-precoated culture dish for $24 \mathrm{~h}$ at $37^{\circ} \mathrm{C}$. After $24 \mathrm{~h}$, culture temperature was lowered at a permissive temperature of $33^{\circ} \mathrm{C}$, and cells attached to the dish were cultured under the same culture condition. To remove contaminated fibroblastic cells from the culture, dispase $(25 \mathrm{U} / \mathrm{ml})$ was added to the culture medium for $24 \mathrm{~h}$. Then the cells with epithelial cell morphology were cloned by colony formation. This procedure was repeated twice [40]. The cells were routinely maintained in DMEM/F12 medium supplemented with 2\% FBS, $1 \%$ ITES and $10 \mathrm{ng} / \mathrm{ml}$ EGF in a collagen type I-precoated culture vessel at $33^{\circ} \mathrm{C}$.

\section{Anchorage-independent growth}

For cell culture in soft agar, the cells were suspended in agar solution which consisted of DMEM/F12 medium supplemented with $0.3 \%$ agar, $1 \%$ ITES, $10 \mathrm{ng} / \mathrm{ml}$ EGF, and $2 \%$ FBS, layered on a semisolid feeder layer, which differed from the agar solution in having a high agar percentage $(0.5 \%)$, and incubated at $33^{\circ} \mathrm{C}$. Two weeks later, the number of colonies was counted under a microscope [42].

\section{Measurements of cell growth and cell cycle}

The number of cells was counted by using a hematocytometer. Cell cycle was determined by flow cytometry as described previously [7]. In short, cells were fixed with 70\% ice-cold ethanol, and subsequently treated with $0.25 \mathrm{mg} / \mathrm{ml} \mathrm{RNase}$ A and $50 \mu \mathrm{g} / \mathrm{ml}$ propidium iodide (PI). The samples were run on an Epics XL flow cytometer (Beckman Coulter, Fullerton, CA, USA).

\section{Immunocytochemistry}

The cells were grown in a collagen type I-precoated eight-well chamber slide. The cells were washed with PBS, fixed in methanol for $7 \mathrm{~min}$ at $25^{\circ} \mathrm{C}$. The cells were incubated with the primary antibody for $18 \mathrm{~h}$ at $4{ }^{\circ} \mathrm{C}$, and placed in the Chromeo ${ }^{\mathrm{TM}}$ 488-labeled secondary antibody (Active Motif, Carlsbad, CA, USA) for $1 \mathrm{~h}$ at $25^{\circ} \mathrm{C}$. The fluorescence was examined under a fluorescence microscope. Primary antibodies used were as follows: mouse monoclonal anti-SV40 large T-antigen antibody (ab16879, Abcam, Cambridge, MA, USA); mouse monoclonal anti-Pcna (proliferating cell nuclear antigen) antibody (sc-56, Santa Cruz Biotechnology, Santa Cruz, CA, USA); rabbit polyclonal anti-cytokeratin antibody
(PAN, Zymed Laboratories, Inc., San Francisco, CA, USA); rabbit polyclonal anti-actin antibody (65-096, ICN ImmunoBiologicals, Lisle, IL, USA); rabbit polyclonal anti-laminin antibody (PS040, Sanbio, AM Uden, The Netherlands); rabbit polyclonal anti-collagen type IV antibody (AB756, Millipore Co., Temecula, CA, USA); mouse monoclonal anti-E-cadherin antibody (610182, BD Biosciences, San Jose, CA, USA); rabbit polyclonal anti-connexin 43 antibody (\#3512, Cell Signaling Technology, Inc., Danvers, MA, USA); normal mouse IgG (PP54, Chemicon International, Inc., Temecula, CA, USA); normal rabbit IgG (02-6102, Zymed Laboratories, Inc.).

\section{Transmission electron microscopy}

For transmission electron microscopic study, cells were fixed with 3\% glutaraldehyde in PBS and osmicated in $1 \%$ osmium tetroxide. After dehydrated in graded aceton solution, they were embedded in Epon 812. Ultrathin sections were stained with lead citrate and uranyl acetate and examined with an H-7100 electron microscope (Hitachi Ltd., Tokyo, Japan) at $75 \mathrm{kV}$.

\section{SDS-polyacrylamide gel electrophoresis and Western blotting}

The cells were washed once with PBS and scraped using a plastic policeman. Cellular material was placed into $50 \mathrm{mM}$ Tris- $\mathrm{HCl}$ buffer ( $\mathrm{pH} 8.0$ ) containing $150 \mathrm{mM}$ $\mathrm{NaCl}$ and 1\% NP-40 and homogenized by an ultrasonic disruptor. SDS-polyacrylamide gel electrophoresis and Western blotting were carried out as described elsewhere $[21,49]$. The polyvinylidene difluoride membranes were incubated with the primary antibody at $4^{\circ} \mathrm{C}$ for $18 \mathrm{~h}$, and exposed to the peroxidase-conjugated secondary antibody at room temperature for $1 \mathrm{~h}$. Immunoreactive proteins were visualized by a luminescent image analyzer using a chemiluminescence detection system. Primary antibodies used were as follows: rabbit polyclonal antiKrt4 antibody (ab51600, Abcam); mouse monoclonal anti-Krt10 antibody (ab9025, Abcam); mouse monoclonal anti-Krt13 antibody (1C7, MUbio Products BV, Oxfordlaan, Maastricht, The Netherlands); mouse monoclonal anti-Krt14 antibody (Millipore Co.); rabbit monoclonal anti-Krt17/19 antibody (\#3984, Cell Signaling Technology, Inc.); mouse monoclonal anti-P63 antibody (sc-8431, Santa Cruz Biotechnology); mouse monoclonal anti-involucrin antibody (ab80530, Abcam); mouse monoclonal anti-Gapdh (glyceraldehyde 3-phosphate 
dehydrogenase) antibody (MAB374, Millipore Co.).

\section{RNA isolation}

Total RNA was extracted from cells using an RNeasy Total RNA Extraction kit (Qiagen, Valencia, CA, USA) along with on-column DNase I treatment. RNA quality was analyzed using a Bioanalyzer 2100 (Agilent Technologies, Inc., Santa Clara, CA, USA). RNA samples that had RIN (RNA integrity number) values above 9.5 were considered acceptable.

Microarray and computational gene expression analyses

Microarray analysis was carried out using a GeneChip ${ }^{\circledR}$ system with a Rat Genome 2302.0 array, which was spotted with 31,099 probe sets (Affymetrix, Inc., Santa Clara, CA, USA) according to the manufacturer's instructions. In brief, $500 \mathrm{ng}$ of total RNA was used to synthesize cRNA with a GeneChip ${ }^{\circledR} 3^{\prime}$ IVT Express Kit (Affymetrix, Inc.). After fragmentation, biotin-labeled cRNA was hybridized to the array at $45^{\circ} \mathrm{C}$ for $16 \mathrm{~h}$. The arrays were washed, stained with streptavidin-phycoerythrin, and scanned using a probe array scanner. The obtained hybridization intensity data were analyzed using GeneSpring ${ }^{\circledR}$ GX (Agilent Technologies, Inc.) to extract the significant genes. To examine gene ontology, including biological processes, cellular components, molecular functions, and gene networks, the obtained data were analyzed using Ingenuity ${ }^{\circledR}$ Pathway Analysis tools (Ingenuity Systems, Inc., Mountain View, CA, USA), a web-delivered application that enables the identification, visualization, and exploration of molecular interaction networks in gene expression data $[1,6]$.

\section{Real-time quantitative polymerase chain reaction (PCR)} assay

Real-time quantitative PCR was performed on an Mx3005P real-time PCR system (Agilent Technologies, Inc.) using SYBR PreMix ExTaq (Takara Bio Inc., Shiga, Japan) or Premix Ex Taq (for the use of TaqMan probes; Takara Bio Inc.) according to the manufacturer's protocols. The reverse transcriptase reaction was carried out with total RNA by using a random 6 mers and an oligo dT primer. PCR primers were designed as based on the databases; Fos (FBJ osteosarcoma oncogene; GenBank Accession No.: NM_022197, sense primer position: 529-550, and antisense primer position: 692673), Gapdh (NM_017008, 775-794, and 1062-1043), Krt13 (NM_001004021, 323-342, and 464-445) and
Prdm 1(PR domain containing 1, with ZNF domain; NM_001107639, 341-360, and 586-567). Based on the database, the specific primers and a probe were designed; Cdkn1 a (cyclin-dependent kinase inhibitor 1A; GenBank Accession No.: U24174, sense primer position: 109-128, antisense primer position: $176-157$, and probe position: 153-174). Each mRNA expression level was normalized with respect to the mRNA expression of Gapdh.

\section{Statistical analysis}

Data are presented as the means \pm SDs. Differences between groups were analyzed by ANOVA, and correction for multiple comparisons was made using Dunnett's multiple comparison test. Statistically significant differences were assumed at $P<0.05$.

\section{Results}

Establishment of an oral epithelial cell line from $T G$ rats

In our series of two attempts, several cell lines were developed from primary cultures of underside epithelial tissues of tongues from feral transgenic rats harboring the mutant oncogene. We chose a cell line, designated ROE2, on the basis of its ability to exhibit an epithelial morphology and protein expression of epithelial cell markers. ROE2 cells had a stable homogeneous epithelial-like morphology and maintained tight connections with neighboring cells at either a permissive temperature of $33^{\circ} \mathrm{C}$ or an intermediate temperature of $37^{\circ} \mathrm{C}$ (Figs. $1 \mathrm{~A}$ and $\mathrm{B})$. When the culture temperature was shifted to a nonpermissive temperature of $39^{\circ} \mathrm{C}$, the cells were significantly larger than they were at the two lower temperatures (Fig. 1C), as was also true in our previous studies [43, 44]. A multilayered cell sheet was observed in ROE2 cells cultured for 9 days at both $33^{\circ} \mathrm{C}$ and $37^{\circ} \mathrm{C}$ but not at $39^{\circ} \mathrm{C}$ (Figs. 1D-F). Electron microscopic observation confirmed that the cells cultured at $37^{\circ} \mathrm{C}$ for 9 days formed a multilayered structure (Figs. $3 \mathrm{~A}$ and B).

\section{Cell growth characteristics}

ROE2 cells proliferated constantly at both $33^{\circ} \mathrm{C}$ and $37^{\circ} \mathrm{C}$, whereas growth decreased significantly at $39^{\circ} \mathrm{C}$ (Fig. 1G), indicating that cell growth is sensitive to temperature. On the other hand, large T-antigen and Pcna were expressed in the nuclei at all temperatures tested (Figs. 2A-F). However, under the negative control conditions, no fluorescence signals were detected in the cells treated with mouse and rabbit normal IgG at $33^{\circ} \mathrm{C}$ (Figs. 

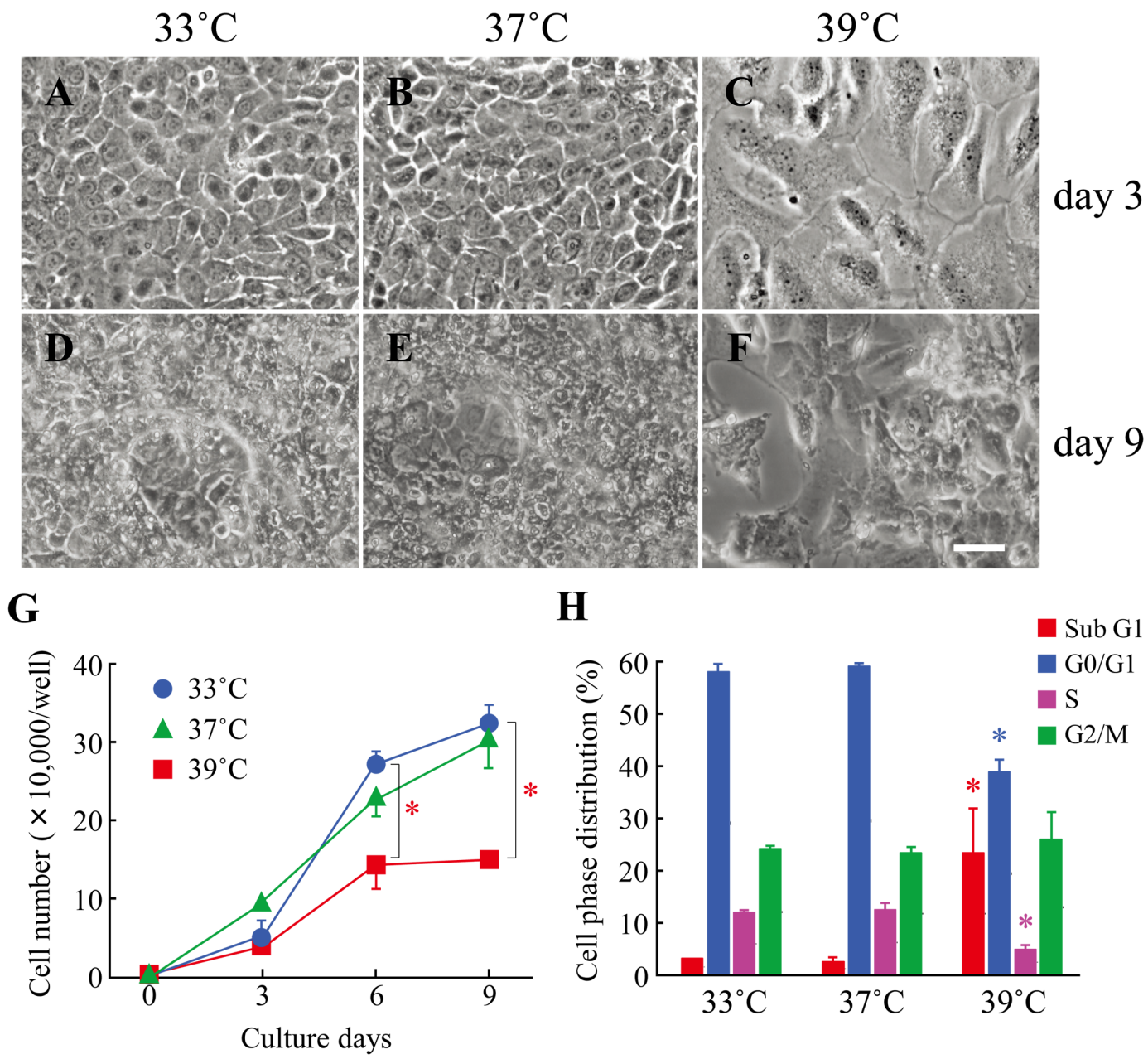

Fig. 1. Effects of culture temperatures on the cell morphology, cell growth and cell cycle in ROE2 cells. The cells were cultured at a permissive temperature $\left(33^{\circ} \mathrm{C}\right)$ followed by culturing at an intermediate temperature $\left(37^{\circ} \mathrm{C}\right)$ and a nonpermissive temperature $\left(39^{\circ} \mathrm{C}\right)$ for $0-9$ days. $(\mathrm{A}-\mathrm{F})$ The cultures were examined microscopically after 3 days $(\mathrm{A}-\mathrm{C})$ and 9 days $(\mathrm{D}-\mathrm{F})$ at different temperature conditions $\left(33^{\circ} \mathrm{C}: \mathrm{A}, \mathrm{D} ; 37^{\circ} \mathrm{C}\right.$ : $\mathrm{B}$, $\left.\mathrm{E} ; 39^{\circ} \mathrm{C}: \mathrm{C}, \mathrm{F}\right)$. Bar, $50 \mu \mathrm{m}$. (G) The number of cells was counted using a hematocytometer. Closed circles, $33^{\circ} \mathrm{C}$; closed triangles, $37^{\circ} \mathrm{C}$; closed squares, $39^{\circ} \mathrm{C}$. ${ }^{*}: P<0.05$ vs. culture at $33^{\circ} \mathrm{C}$ (Dunnett's multiple comparison test). (H) The cells were cultured at different temperatures for 3 days, and then cell phase distribution in the cell cycle was monitored by using a flow cytometer. Red columns, sub G1 phase; blue columns, G0/G1 phase; red-purple columns, S phase; green columns, G2/M phase. *: $P<0.05$ vs. each control (culture at $33^{\circ} \mathrm{C}$ ) (Dunnett's multiple comparison test).

$2 \mathrm{M}-\mathrm{P})$, and almost no signals were detected at the higher temperatures of $37^{\circ} \mathrm{C}$ and $39^{\circ} \mathrm{C}$ (data not shown). Next, the cell-cycle distribution was monitored by PI staining with flow cytometry. The percentages of ROE2 cells at $33^{\circ} \mathrm{C}$ in the sub-G1, G0/G1, S, and G2/M phases were $3.2 \pm 0.2 \%, 58.0 \pm 1.4 \%, 12.0 \pm 0.7 \%$, and 24.2 $\pm 0.7 \%$ (mean $\pm \mathrm{SD}$ ), respectively. No changes in the distribution of cell-cycle phases were observed at $37^{\circ} \mathrm{C}$. Cells cultured at $39^{\circ} \mathrm{C}$ showed significantly lower percentages of $\mathrm{G} 0 / \mathrm{G} 1$ and $\mathrm{S}$ phases (Fig. 1H). In contrast, those cultured at $39^{\circ} \mathrm{C}$ showed marked elevation of the
sub-G1 phase of the cell cycle, a marker for apoptosis, compared to those at $33^{\circ} \mathrm{C}$ and $37^{\circ} \mathrm{C}$; the percentage of sub-G1 in the cell cycle at $39^{\circ} \mathrm{C}$ was $23.4 \pm 8.4 \%$ (mean $\pm \mathrm{SD} ; 3.2 \pm 0.2 \%$ at $33^{\circ} \mathrm{C}$ ). These data indicate that the nonpermissive temperature induces apoptosis.

ROE2 cells have been maintained in culture for approximately one year at $33^{\circ} \mathrm{C}$, with stable morphological phenotype. Moreover, when the cells were cultured in a soft agar gel at $33^{\circ} \mathrm{C}$, the cells did not show any colonyforming activity (data not shown). These data thus demonstrated that ROE2 cells are only immortalized and not 


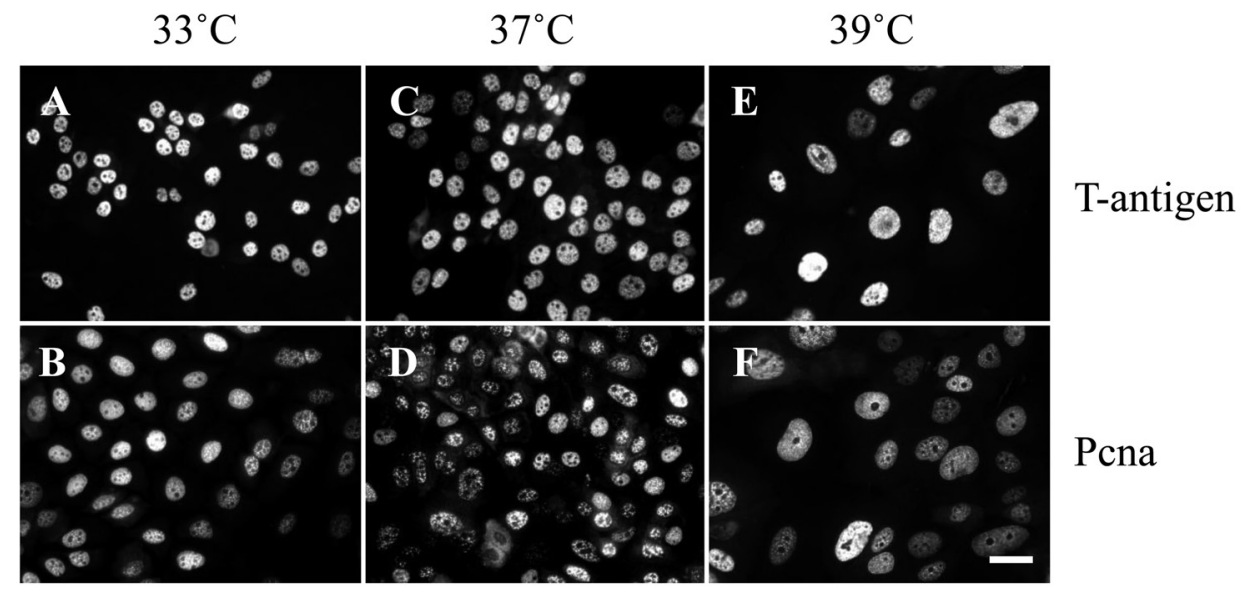

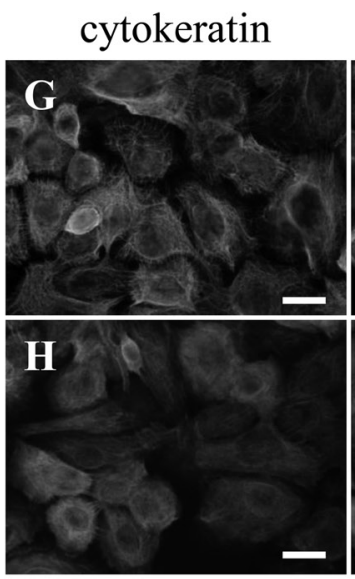

actin
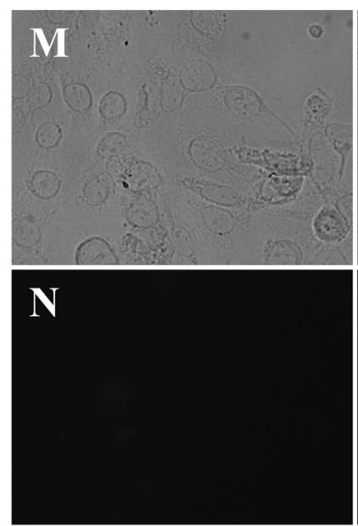

mouse IgG laminin
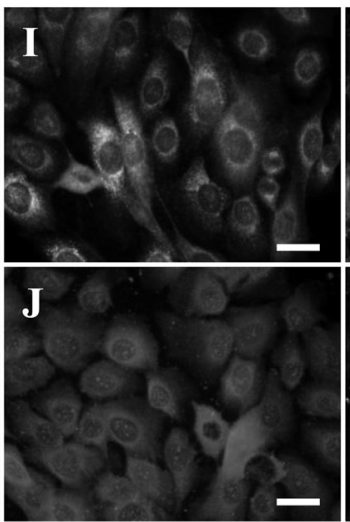

collagen type IV
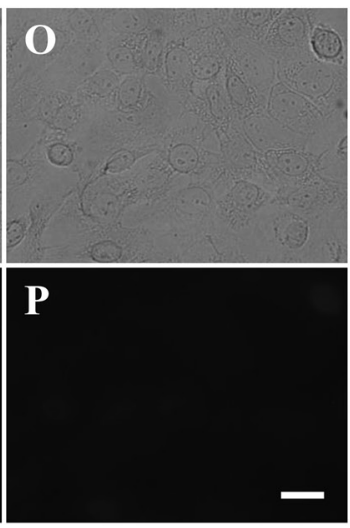

rabbit IgG

\section{DICI}

FI

Fig. 2. Expressions of nuclear, cytoskeletal, basement, and junctional proteins in ROE2 cells. (A-F) The cells were cultured at different temperatures for 3 days. Immunocytochemical analyses of nuclear proteins, large T-antigen (A, C, E) and Pcna (B, D, F) at $33^{\circ} \mathrm{C}(\mathrm{A}, \mathrm{B}), 37^{\circ} \mathrm{C}(\mathrm{C}, \mathrm{D})$ and $39^{\circ} \mathrm{C}(\mathrm{E}, \mathrm{F}) .(\mathrm{G}-\mathrm{L})$ The cells were cultured at $33^{\circ} \mathrm{C}$ for 3 days. Immunocytochemical analyses of cytoskeletal proteins, cytokeratin $(\mathrm{G})$ and actin $(\mathrm{H})$, basement proteins, laminin (I) and collagen type IV (J), and junctional proteins, E-cadherin (K) and connexin 43 (L). (M-P) The cells were cultured at $33^{\circ} \mathrm{C}$ for 3 days. Immnocytochemical analyses of normal mouse $\operatorname{IgG}(\mathrm{M}, \mathrm{N})$ and normal rabbit $\operatorname{IgG}(\mathrm{O}, \mathrm{P})$. Differential interference contrast images (DICI) $(\mathrm{M}, \mathrm{O})$ and fluorescence images (FI) (N, P) are shown. Bar, $25 \mu \mathrm{m}$. 


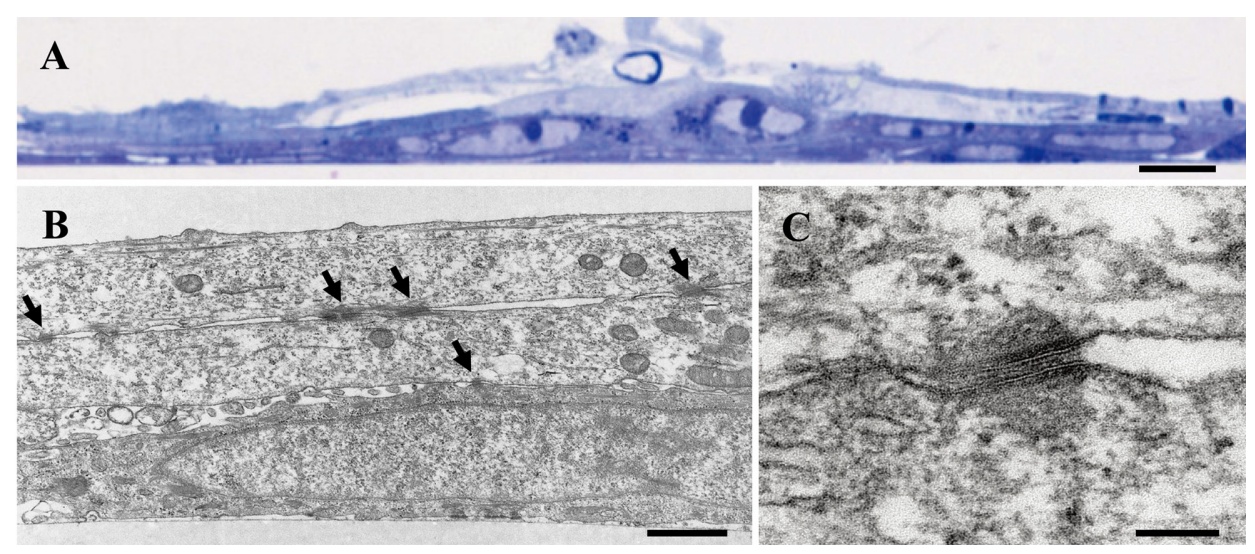

Fig. 3. Transmission electron micrographs of ROE2 cells. The cells were cultured at $37^{\circ} \mathrm{C}$ for 9 days. (A) A low-magnification image of the semi-thin section stained with toluidine blue. (B) Section cut perpendicular to the plane of the dish. Arrows indicate desmosomes. (C) Higher magnification of desmosome. Bar in A, $10 \mu \mathrm{m}$; bar in $\mathrm{B}, 1 \mu \mathrm{m}$; bar in $\mathrm{C}, 0.1 \mu \mathrm{m}$.

transformed. Although immortalized cell lines by infection with the SV40 large T-antigen occasionally undergo malignant transformation [14], no transformed cell lines developed from the TG mice $[40,42]$ and rats $[43,44]$ that harbor tsSV40 large T-antigen.

\section{Expressions of marker proteins for epithelial cells}

We investigated the epithelial phenotype of an established cell line. Immunocytochemical investigations demonstrated that the cytoskeletal proteins cytokeratin and actin; basement membrane proteins laminin and collagen type IV; and junctional complex proteins E-cadherin and connexin 43 were detected in the ROE2 cells at $33^{\circ} \mathrm{C}$ (Figs. $2 \mathrm{G}-\mathrm{L}$ ). In addition, under electron microscopic observations, when the cells were cut parallel to the plane of the dish, several desmosomes were observed between the cells in the multilayered sheet of ROE2 cells (Figs. 3B, C). These results provide strong evidence that this cell line preserves some characteristics of oral epithelial cells, as in the cases of mouse gingival epithelial cell lines from TG mice bearing the tsSV40 large Tantigen [12], human buccal epithelial cell line SVpgC2a transformed by SV40 large T-antigen [11], and human oral primary epithelial cell cultures $[2,11]$.

The assessment of the expression of different cytokeratin subtypes is very useful for identifying cell types in oral epithelia [36, 37]. Cells of the basal layer in both oral keratinized and nonkeratinized epithelia express Krt14, whereas Krt10 or Krt4 and Krt13 are found in cells of the spinous layer in keratinized epithelia or the intermediate layer in nonkeratinized epithelia, respec-

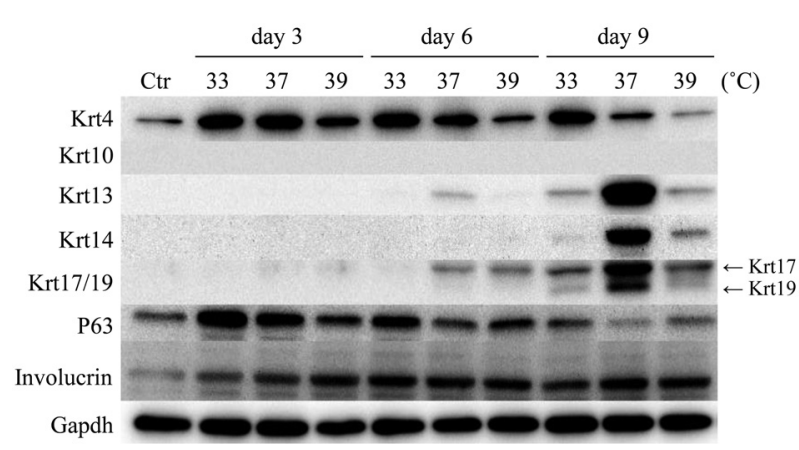

Fig. 4. Effects of culture periods and culture temperatures on protein expressions for cytokeratins, P63 and involucrin in ROE2 cells. The cells were cultured at different temperatures for 3, 6, and 9 days. Western blot analyses were performed with specific primary antibodies for Krt4, Krt10, Krt13, Krt14, Krt17/19, P63, involucrin, and Gapdh. Gapdh served as a loading control. Ctr, control (day 0).

tively. In addition, Krt19 [24] and P63 [31] are reported to be good candidates for epidermal stem cell markers. Involucrin is used as a marker of oral epithelial cell differentiation $[32,38]$. Figure 4 shows the protein levels of cytokeratins, P63, and involucrin, as demonstrated by Western blotting under different temperature conditions. Krt4 was expressed at all temperature conditions, and the level was higher at $33^{\circ} \mathrm{C}$ than at $37^{\circ} \mathrm{C}$ or $39^{\circ} \mathrm{C}$. The expression levels of Krt13, Krt14, Krt17, and Krt19 were below the detection limit under control conditions. Culturing for 9 days induced significant expression levels of $\mathrm{Krt13}, \mathrm{Krt14}, \mathrm{Krt17}$, and $\mathrm{Krt19}$ at $33^{\circ} \mathrm{C}, 37^{\circ} \mathrm{C}$, and $39^{\circ} \mathrm{C}$, and remarkable elevations of these four cytokeratins were observed in $\mathrm{ROE} 2$ cells at $37^{\circ} \mathrm{C}$. On the other 
hand, Krt10 was not expressed under any experimental conditions. The peak expression of P63 was detected at 3 days of culture, and the level gradually and time-dependently decreased under all temperature conditions. A constant expression of involucrin was maintained throughout the experiment under all conditions employed (Fig. 4).

Global-scale gene expression and functional category analyses

To identify genes involved in ROE2 cell differentiation, global-scale gene expression analysis was carried out using the GeneChip ${ }^{\circledR}$ system. We detected 11,264 probe sets that were expressed in ROE2 cells cultured at $37^{\circ} \mathrm{C}$ for 3-9 days. The complete lists of genes from ROE2 cell samples have been deposited in the Gene Expression Omnibus (GEO), a public database (an accession number: GSE44560). Expression analysis using GeneSpring ${ }^{\circledR}$ software revealed many probe sets that were differentially regulated by a factor of 2.0 or greater. We found a total of 1,495 probe sets; 924 upregulated and 571 downregulated. Moreover, K-means clustering, a nonhierarchical gene clustering algorithm, was performed to generate the major patterns of gene expression during cell differentiation. Differentially expressed probe sets were grouped in four clusters with distinct expression profiles, designated Up-I, Up-II, Up-III, and Down-I, which included 202, 135, 587, and 571 probe sets, respectively. The Up-I cluster contained gradually increased probe sets whose peak expressions occurred at day 3; the Up-II cluster contained increased probe sets whose basal expression levels at day 0 were very low. The expression levels of probe sets in the Up-III and Down-I clusters gradually increased and decreased, respectively (Fig. 5).

Functional category analyses of differentially ex- pressed probe sets in each cluster were conducted by using the Ingenuity ${ }^{\circledR}$ Pathways Knowledge Base. The top biological function and associated genes in each cluster are summarized in Table 1. The top biological function in the upregulated gene cluster Up-I was amino acid metabolism, which was functionally annotated with the synthesis of amino acids and included 7 genes. In the downregulated gene cluster Down-I, the top biological function was cellular movement, which was functionally annotated with the invasion of cells and included 37 genes. Furthermore, the top biological function, organ development, which was functionally an-
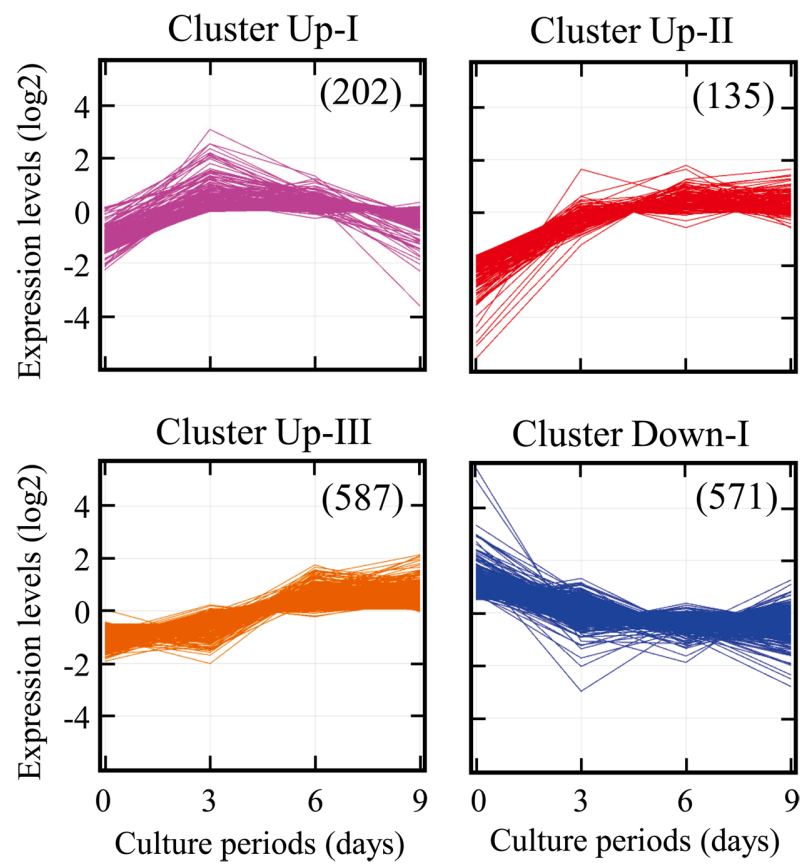

Cluster Down-I

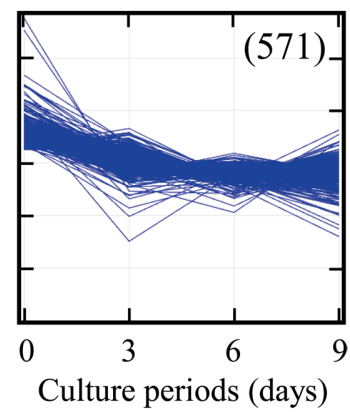

Fig. 5. Gene expression analysis. ROE2 cells were cultured at $37^{\circ} \mathrm{C}$ for $0-9$ days. K-means clustering of the probe sets that were differentially expressed by a factor of 2.0 or greater was performed using bioinformatics analysis tools. Figures in the parentheses indicate probe sets numbers.

Table 1. The top biological function and associated genes in each cluster

\begin{tabular}{llll}
\hline Cluster & \multicolumn{1}{c}{ Category } & Functional annotation (P-value) & \multicolumn{1}{c}{ Molecules (numbers) } \\
\hline Up-I & Amino acid metabolism & Synthesis of amino acids (7.05E-06) & Asns, Cth, Egr1, Gch1, Phgdh, Pycr1, Slcla3 (7) \\
Up-II & Organ development & Skin development (1.34E-05) & Abhd5, Asprv1, Elovl4, Grhl3, Krt1, Krt13, Krt15, Lor, Prdm1 (9) \\
Up-III & Organ development & Skin development (1.05E-06) & Bmp4, Calml5, Ccnd2, Cdkn1a, Celsr1, Egfr, Eif2c2, Errfi1, Evpl, \\
& & & Foxe1, Gba, Krtdap, Nab1, Prss8, Rbp2, Scel, Spink5, Tacstd2, \\
& & & Tfap2a, Tgfb2, Tgm1, Tgm3, Ugcg (23) \\
Down-I & Cellular movement & Invasion of cells (1.22E-04) & Acsl4, Apex1, Areg/Aregb, B4galt5, Capn2, Casp3, Cd14, Csf3, \\
& & & Dab2, Dock1, F2r, Fgf13, Fhl2, Fhod1, Fn1, Frk, Fstl1, Gna12, \\
& & & Gzmb, Id2, Itgb6, Kitlg, Lama5, Mmp3, Ppic, Ptgs2, Pxn, Rras2, \\
& & Ruvbl1, Sdc2, Serpine2, Slc12a2, Sod2, Spry2, Timp1, Traf3, Vim (37) \\
\hline
\end{tabular}


notated with skin development, was observed in both upregulated clusters Up-II and Up-III. Nine genes, including Krt13, Lor (loricrin), and Prdm 1; and 23 genes, including Cdkn 1a, Egfr (epidermal growth factor receptor), and $\operatorname{Tgm}$ (transglutaminase) 1 , were associated with skin development in clusters Up-II and Up-III, respectively (Table 1).

\section{Gene network analysis}

To define the molecular mechanism underlying cell differentiation induced by culturing at $37^{\circ} \mathrm{C}$, we performed gene network analysis on upregulated genes belonging to clusters Up-II and Up-III using the Ingenuity Pathways Knowledge Base. We found a significant gene network, D, which included Cdknla, Egfr, Fos, Krt13, and $\operatorname{Prdm} 1$ (a total of 16 genes). Interestingly, almost all genes in the gene network D were associated with skin development (functions annotation) in the category of biological functions (organ development) (Fig. 6). To verify the results of the microarrays, we performed a real-time quantitative PCR assay. Four genes-Cdknla, Fos, Krt13, and Prdm1-were selected from the genes that belonged to the gene network and were upregulated by culturing at $37^{\circ} \mathrm{C}$ for $3-9$ days. As shown in Fig. 7, the expression levels of the four genes were significantly upregulated in the case of cell culturing at $37^{\circ} \mathrm{C}$. This was almost comparable to the results of microarray analysis.

\section{Discussion}

TG mice harboring tsSV40 large T-antigen have been found to be a good source for establishing immortalized cell lines from many kinds of tissues including epithelia $[27,28]$. The aim of this study, the development of an oral epithelial cell line with differentiation potential, was achieved by using TG rats. Interestingly, rat oral epithelial cell line ROE2, which was established here, retained some functions of stratified oral epithelial cells and differentiated into nonkeratinized epithelial cells under standard culture conditions. To our knowledge, this is the first report regarding the establishment of an oral epithelial cell line having differentiation potential from TG rats harboring the mutant oncogene.

It has been well known that wild-type SV40 large Tantigen induces immortalization by inactivating functions of several tumor suppressor molecules, such as p53 and retinoblastoma binding protein (pRb) [41]. In con- trast, mutant tsSV40 large T-antigen can form complexes with $\mathrm{p} 53$ and $\mathrm{pRb}$ at permissive temperatures but at nonpermissive temperatures is inactivated and degraded and releases $\mathrm{p} 53$ or $\mathrm{pRb}$ from the complexes $[16,55]$. A variety of the cell lines developed from TG animals harboring the mutant oncogene exhibited temperature-dependent growth characteristics, and nonpermissive temperatures induced cell differentiation or cell growth arrest accompanying apoptosis [28]. In the present study, although ROE2 cells showed temperature-sensitive growth, the expression levels of large T-antigen and Pcna, a valuable marker for S-phase cells, did not decrease in the nonpermissive temperature of $39^{\circ} \mathrm{C}$. However, cell-cycle analysis demonstrated that the culture at $39^{\circ} \mathrm{C}$ significantly increased in the sub-G1 phase, a marker for apoptosis, but decreased in the S-phase in the cell cycle. We thought the immortalization and growth of ROE2 cells were due to the expression of tsSV40 large T-antigen. However, further studies are needed to investigate the molecular mechanism underling nonpermissive temperature-induced apoptosis in ROE2 cells.

In cell lines established from TG animals harboring the tsSV40 large T-antigen, their differentiated phenotypes were usually observed under nonpermissive temperature conditions at $39^{\circ} \mathrm{C}$ [28]. However, when apoptosis is induced by the culture at $39^{\circ} \mathrm{C}$, differentiated phenotypes are reported to be detected even at the intermediate temperatures of $37^{\circ} \mathrm{C}$ or the permissive temperatures of $33^{\circ} \mathrm{C}[12,48]$. In line with these findings, the most differentiated phenotype of ROE2 cells was found to be long-term culture at $37^{\circ} \mathrm{C}$. Under the differentiated conditions, ROE2 cells expressed not only superficial and intermediate layer cell markers, Krt4, Krt13, and involucrin, but also basal layer cell markers, Krt14, Krt19, and P63 [31, 32, 38], indicating that the culture may include several transit cells that show distinct types of cell differentiation.

To clarify the molecular mechanism underling the differentiation of ROE 2 cells at $37^{\circ} \mathrm{C}$, we further performed global-scale comprehensive microarray and computational gene expression analyses. The results showed changes in gene expression and gene network D involved in the cell differentiation of ROE2 cells. Very interestingly, the top biological function in both upregulated gene clusters Up-II and Up-III was the biological process of skin development. Among a total of 32 genes identified $(9+23$; Table 1), 28 genes (the exceptions being Prdm1, Calml5(calmodulin-like 5), Foxel(forkhead box E1), and 


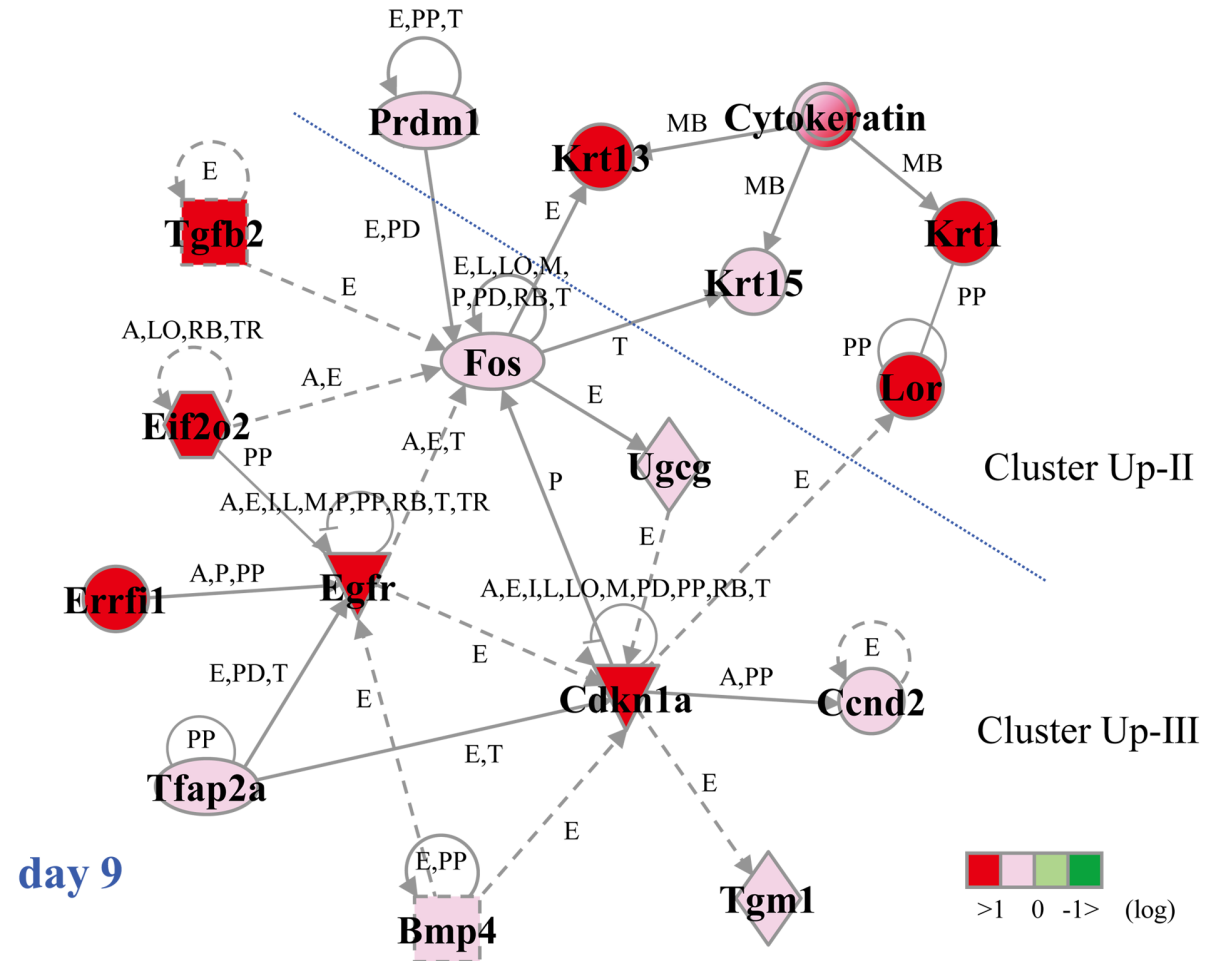

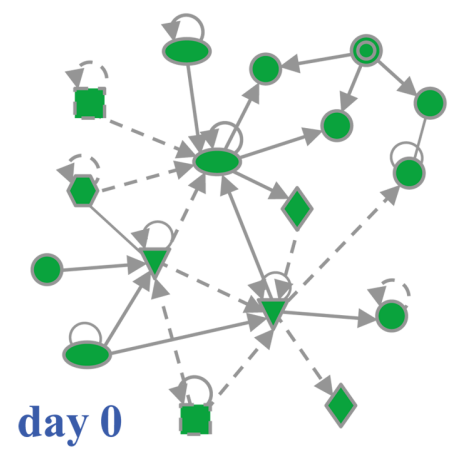

day 3

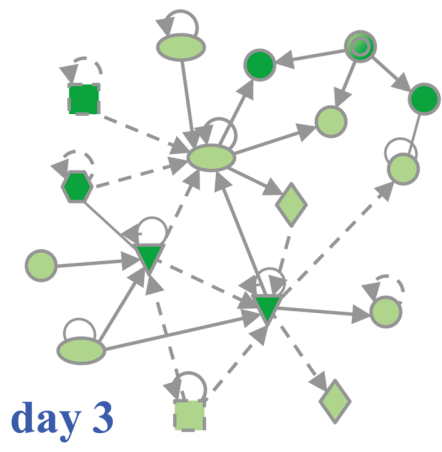

Edge labels

P, phosphorylation/dephosphorylation

PD, protein-DNA binding

PP, protein-protein binding

$\mathbf{R B}$, regulation of binding

$\mathbf{T}$, transcription

TR, translocation

M, modification

MB, member

$$
\begin{aligned}
& \text { (A) binding only } \\
& \text { A } \\
& \text { A B }
\end{aligned}
$$

Fig. 6. The gene network D. ROE2 cells were cultured at $37^{\circ} \mathrm{C}$ for $0-9$ days. Probe sets that were up-regulated in the clusters Up-II and Up-III were analyzed by the Ingenuity Pathway analysis software. The network is displayed graphically as nodes (genes) and edges (the biological relationships between the nodes). Nodes and edges are displayed various shapes and labels that present the functional class of genes and the nature of the relationship between the nodes, respectively. 
A

\section{Cdkn1a}

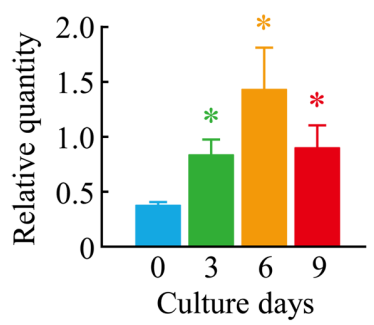

B

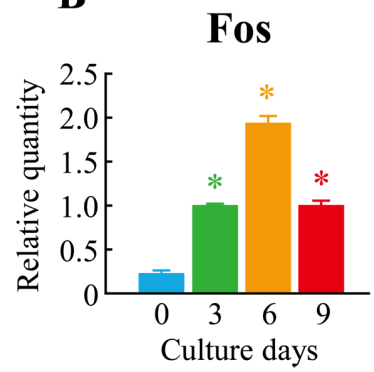

C

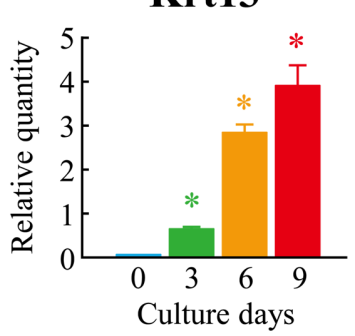

D

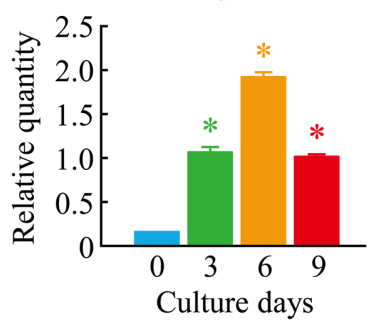

Fig. 7. Verification of microarray results by real-time quantitative PCR. The cells were cultured at $37^{\circ} \mathrm{C}$ for $0-9$ days. Realtime quantitative PCR was performed. Each expression level was normalized by Gapdh. (A)Cdknla; (B)Fos; (C) Krt13; (D)Prdm1. The data represent means \pm SDs from 4 different experiments. $* P<0.05$ vs. control (day 0) (Dunnett's multiple comparison test).

Tfap $2 a$ (transcription factor AP-2 alpha)) were also found to be expressed in normal differentiated keratinocytes in mouse oral mucosa [53], the gene expression data of which were obtained from GEO, an accession number of GSE28035. In these genes, it has been reported that Evpl (envoplakin) [35], Scel (sciellin) [4], $\operatorname{Tgm} 1$ [8], and $\operatorname{Tgm} 3$ [56] are involved in the development of epidermis. In this study, of particular interest was our identification of the skin development-associated gene network D, whose core contains Cdknla, Egfr, and $F o s$ derived from upregulated genes in cluster Up-II or Up-III. Krt13 is a marker protein for oral nonkeratinized and differentiated epithelial cells [32,38], and is shown to play an important role in epidermal development. Richard et al. [33] presented evidence to support the notion that morphological changes, including epithelial thickening, parakeratosis, and extensive vacuolization of the suprabasal keratinocytes in the upper spinous layers occur in epidermal disorders due to Krt13 defects. Previous findings also demonstrated that Prdm1 [23] and Cdkn1a [30] are involved in the terminal differentiation of epidermis. Moreover, as regards the gene

network D, relationships have been reported between Fos and Krt13, and between both of these and Cdkn1a and Prdm1; namely, the downregulation of Krt13 was observed in skin keratinocytes of Fos-deficient mice [5], Cdkn1a increased the phosphorylation of Fos [26], and Fos elevated the expression level of Prdm1 [29]. According to previous findings, Lor [22], Tfap2a [50], and Ugcg (UDP-glucose ceramide glucosyltransferase) [51] are involved in keratinocyte differentiation. Bmp4 (bone morphogenetic protein 4) [10] and Ccnd2 (cyclin D2) [34] are also reported to positively regulate epidermis morphology in experimental animal models. The differentially expressed genes and/or acted within the gene network D identified here are likely to be involved in the differentiation of ROE2 cells. However, the interaction between gene expression and cell differentiation is as yet not fully understood. Important questions need to be elucidated in further investigations.

Recently, Alaminos et al. [2] reported that the expression of 1,085 genes was upregulated at least 10 -fold in stratified differentiated cells in comparison to monolayer undifferentiated cells formed using human normal oral epithelial cells on fibrin-agarose scaffolds. For the expression profiles of these 1,085 genes, we identified 44 genes involved in skin development by using computational gene expression analysis tools. In 44 genes, only 6 genes-Calml5, Celsr 1 (cadherin, EGF LAG seven-pass G-type receptor 1), Evpl, Krtdap (keratinocyte differentiation associated protein), Scel, and Spink5 (serine peptidase inhibitor, Kazal type 5)-were upregulated under differentiated conditions in both ROE2 cells and the human oral culture system [2]. This discrepancy may be due to cell-type differences and different experimental conditions, such as culture conditions, or to differences in the analytical methods used.

In conclusion, rat oral epithelial cell line ROE2 having specific functions would be useful as an in vitro model for studies of physiological functions and of gene expression in oral epithelial cells. In addition, the established cell line may offer an alternative to experiments using living animals, thereby providing a solution to ethical issues.

\section{Acknowledgments}

This study was supported in part by a Grant-in-Aid for Challenging Exploratory Research (23650303) and a Grant-in-Aid for Scientific Research B (24310046) 
from Japan Society for the Promotion of Science, and by research grants from the University of Toyama.

\section{References}

1. Ahmed, K., Furusawa, Y., Tabuchi, Y., Emam, H.F., Piao, J.L., Hassan, M.A., Yamamoto, T., Kondo, T., and Kadowaki, M. 2012. Chemical inducers of heat shock proteins derived from medicinal plants and cytoprotective genes response. Int. J. Hyperthermia 28: 1-8. [Medline] [CrossRef]

2. Alaminos, M., Garzón, I., Sánchez-Quevedo, M.C., Moreu, G., González-Andrades, M., Fernández-Montoya, A., and Campos, A. 2007. Time-course study of histological and genetic patterns of differentiation in human engineered oral mucosa. J. Tissue Eng. Regen. Med. 1: 350-359. [Medline] [CrossRef]

3. Araki, Y., Suzuki, K., Matusik, R.J., Obinata, M., and Orgebin-Crist, M.C. 2002. Immortalized epididymal cell lines from transgenic mice overexpressing temperature-sensitive simian virus 40 large T-antigen gene. J. Androl. 23: 854-869. [Medline]

4. Champliaud, M.F., Baden, H.P., Koch, M., Jin, W., Burgeson, R.E., and Viel, A. 2000. Gene characterization of sciellin (SCEL) and protein localization in vertebrate epithelia displaying barrier properties. Genomics 70: 264-268. [Medline] [CrossRef]

5. Durchdewald, M., Guinea-Viniegra, J., Haag, D., Riehl, A., Lichter, P., Hahn, M., Wagner, E.F., Angel, P., and Hess, J. 2008. Podoplanin is a novel fos target gene in skin carcinogenesis. Cancer Res. 68: 6877-6883. [Medline] [CrossRef]

6. Furusawa, Y., Tabuchi, Y., Wada, S., Takasaki, I., Ohtsuka, K., and Kondo, T. 2011. Identification of biological functions and gene networks regulated by heat stress in U937 human lymphoma cells. Int. J. Mol. Med. 28: 143-151. [Medline]

7. Furusawa, Y., Iizumi, T., Fujiwara, Y., Zhao, Q.L., Tabuchi, Y., Nomura, T., and Kondo, T. 2012. Inhibition of checkpoint kinase 1 abrogates $\mathrm{G} 2 / \mathrm{M}$ checkpoint activation and promotes apoptosis under heat stress. Apoptosis 17: 102-112. [Medline] [CrossRef]

8. Gentile, V. and Cooper, A.J. 2004. Transglutaminases - possible drug targets in human diseases. Curr. Drug Targets CNS Neurol. Disord. 3: 99-104. [Medline] [CrossRef]

9. Gilchrist, E.P., Moyer, M.P., Shillitoe, E.J., Clare, N., and Murrah, V.A. 2000. Establishment of a human polyclonal oral epithelial cell line. Oral Surg. Oral Med. Oral Pathol. Oral Radiol. Endod. 90: 340-347. [Medline] [CrossRef]

10. Goswami, M., Uzgare, A.R., and Sater, A.K. 2001. Regulation of MAP kinase by the BMP-4/TAK1 pathway in Xenopus ectoderm. Dev. Biol. 236: 259-270. [Medline] [CrossRef]

11. Hansson, A., Bloor, B.K., Sarang, Z., Haig, Y., Morgan, P.R., Stark, H.J., Fusenig, N.E., Ekstrand, J., and Grafström, R.C. 2003. Analysis of proliferation, apoptosis and keratin expression in cultured normal and immortalized human buccal keratinocytes. Eur. J. Oral Sci. 111: 34-41. [Medline] [CrossRef]

12. Hatakeyama, S., Ohara-Nemoto, Y., Yanai, N., Obinata, M.,
Hayashi, S., and Satoh, M. 2001. Establishment of gingival epithelial cell lines from transgenic mice harboring temperature sensitive simian virus 40 large T-antigen gene. J. Oral Pathol. Med. 30: 296-304. [Medline] [CrossRef]

13. Hosoya, K., Tomi, M., Takayama, M., Komokata, Y., Nakai, D., Tokui, T., Nishimura, K., Ueda, M., Obinata, M., Hori, S., Ohtsuki, S., Amidon, G.L., and Terasaki, T. 2004. Transporter mRNA expression in a conditionally immortalized rat small intestine epithelial cell line (TR-SIE). Drug Metab. Pharmacokinet. 19: 264-269. [Medline] [CrossRef]

14. Isom, H.C., Tevethia, M.J., and Kreider, J.W. 1981. Tumorigenicity of simian virus 40-transformed rat hepatocytes. Cancer Res. 41: 2126-2134. [Medline]

15. Jat, P.S., and Sharp, P.A. 1986. Large T antigens of simian virus 40 and polyomavirus efficiently establish primary fibroblasts. J. Virol. 59: 746-750. [Medline]

16. Jat, P.S. and Sharp, P.A. 1989. Cell lines established by a temperature-sensitive simian virus 40 large-T-antigen gene are growth restricted at the nonpermissive temperature. Mol. Cell Biol. 9: 1672-1681. [Medline]

17. Jepsen, A. 1974. An in vitro model of an oral keratinizing squamous epithelium. Scand. J. Dent. Res. 82: 144-146. [Medline]

18. Jepsen, A., MacCallum, D.K., and Lillie, J.H. 1980. Fine structure of subcultivated stratified squamous epithelium. Exp. Cell Res. 125: 141-152. [Medline] [CrossRef]

19. Krause, C.J., Carey, T.E., Ott, R.W., Hurbis, C., McClatchey, K.D., and Regezi, J.A. 1981. Human squamous cell carcinoma. Establishment and characterization of new permanent cell lines. Arch. Otolaryngol. 107: 703-710. [Medline] [CrossRef]

20. Kulkarni, P.S., Sundqvist, K., Betsholtz, C., Höglund, P., Wiman, K.G., Zhivotovsky, B., Bertolero, F., Liu, Y., and Grafström, R.C. 1995. Characterization of human buccal epithelial cells transfected with the simian virus $40 \mathrm{~T}$-antigen gene. Carcinogenesis 16: 2515-2521. [Medline] [CrossRef]

21. Laemmli, U.K. 1970. Cleavage of structural proteins during the assembly of the head of bacteriophage T4. Nature 227: 680-685. [Medline] [CrossRef]

22. Lee, C.H., Marekov, L.N., Kim, S., Brahim, J.S., Park, M.H., and Steinert, P.M. 2000. Small proline-rich protein 1 is the major component of the cell envelope of normal human oral keratinocytes. FEBS Lett. 477: 268-272. [Medline] [CrossRef]

23. Magnúsdóttir, E., Kalachikov, S., Mizukoshi, K., Savitsky, D., Ishida-Yamamoto, A., Panteleyev, A.A., and Calame, K. 2007. Epidermal terminal differentiation depends on B lymphocyte-induced maturation protein-1. Proc. Natl. Acad. Sci. USA. 104: 14988-14993. [Medline] [CrossRef]

24. Michel, M., Török, N., Godbout, M.J., Lussier, M., Gaudreau, P., Royal, A., and Germain, L. 1996. Keratin 19 as a biochemical marker of skin stem cells in vivo and in vitro: keratin 19 expressing cells are differentially localized in function of anatomic sites, and their number varies with donor age and culture stage. J. Cell Sci. 109: 1017-1028. [Medline]

25. Momose, F., Araida, T., Negishi, A., Ichijo, H., Shioda, S., and Sasaki, S. 1989. Variant sublines with different meta- 
static potentials selected in nude mice from human oral squamous cell carcinomas. J. Oral Pathol. Med. 18: 391-395. [Medline] [CrossRef]

26. Neise, D., Sohn, D., Budach, W., and Jänicke, R.U. 2010. Evidence for a differential modulation of p53-phosphorylating kinases by the cyclin-dependent kinase inhibitor $\mathrm{p} 21^{\mathrm{WAF} 1 /}$ CIP1. Cell Cycle 9: 3575-3583. [Medline] [CrossRef]

27. Noble, M., Groves, A.K., Ataliotis, P., Ikram, Z., and Jat, P.S. 1995. The H-2K $\mathrm{K}^{\mathrm{b}}$ tsA58 transgenic mouse: a new tool for the rapid generation of novel cell lines. Transgenic Res. 4: 215-225. [Medline] [CrossRef]

28. Obinata, M. 2007. The immortalized cell lines with differentiation potentials: their establishment and possible application. Cancer Sci. 98: 275-283. [Medline] [CrossRef]

29. Ohkubo, Y., Arima, M., Arguni, E., Okada, S., Yamashita, K., Asari, S., Obata, S., Sakamoto, A., Hatano, M., O-Wang, J., Ebara, M., Saisho, H., and Tokuhisa, T. 2005. A role for c-fos/activator protein 1 in B lymphocyte terminal differentiation. J. Immunol. 174: 7703-7710. [Medline]

30. Paramio, J.M., Segrelles, C., Ruiz, S., Martin-Caballer, J., Page, A., Martinez, J., Serrano, M., and Jorcano, J.L. 2001. The ink ${ }^{4 a / a r f}$ tumor suppressors cooperate with $\mathrm{p} 21^{\mathrm{cip} 1 / \mathrm{waf}}$ in the processes of mouse epidermal differentiation, senescence, and carcinogenesis. J. Biol. Chem. 276: 44203-44211. [Medline] [CrossRef]

31. Pellegrini, G., Dellambra, E., Golisano, O., Martinelli, E., Fantozzi, I., Bondanza, S., Ponzin, D., McKeon, F., and De Luca, M. 2001. p63 identifies keratinocyte stem cells. Proc. Natl. Acad. Sci. USA. 98: 3156-3161. [Medline] [CrossRef]

32. Presland, R.B., and Jurevic, R.J. 2002. Making sense of the epithelial barrier: what molecular biology and genetics tell us about the functions of oral mucosal and epidermal tissues. J. Dent. Educ. 66: 564-574. [Medline]

33. Richard, G., De Laurenzi, V., Didona, B., Bale, S.J., and Compton, J.G. 1995. Keratin 13 point mutation underlies the hereditary mucosal epithelial disorder white sponge nevus. Nat. Genet. 11: 453-455. [Medline] [CrossRef]

34. Rodriguez-Puebla, M.L., LaCava, M., Miliani De Marval, P.L., Jorcano, J.L., Richie, E.R., and Conti, C.J. 2000. Cyclin D2 overexpression in transgenic mice induces thymic and epidermal hyperplasia whereas cyclin D3 expression results only in epidermal hyperplasia. Am. J. Pathol. 157: 1039-1050. [Medline] [CrossRef]

35. Ruhrberg, C., Hajibagheri, M.A., Simon, M., Dooley, T.P., and Watt, F.M. 1996. Envoplakin, a novel precursor of the cornified envelope that has homology to desmoplakin. $J$. Cell Biol. 134: 715-729. [Medline] [CrossRef]

36. Sakamoto, K., Aragaki, T., Morita, K., Kawachi, H., Kayamori, K., Nakanishi, S., Omura, K., Miki, Y., Okada, N., Katsube, K., Takizawa, T., and Yamaguchi, A. 2011. Downregulation of keratin 4 and keratin 13 expression in oral squamous cell carcinoma and epithelial dysplasia: a clue for histopathogenesis. Histopathology 58: 531-542. [Medline] [CrossRef]

37. Sawaf, M.H., Ouhayoun, J.P., and Forest, N. 1991. Cytokeratin profiles in oral epithelial: a review and a new classification. J. Biol. Buccale. 19: 187-198. [Medline]

38. Squier, C.A. and Kremer, M.J. 2001. Biology of oral mu- cosa and esophagus. J. Natl. Cancer Inst. Monogr. 29: 7-15. [Medline] [CrossRef]

39. Sugiyama, N., Tabuchi, Y., Horiuchi, T., Obinata, M., and Furusawa, M. 1993. Establishment of gastric surface mucous cell lines from transgenic mice harboring temperature-sensitive simian virus 40 large T-antigen gene. Exp. Cell Res. 209: 382-387. [Medline] [CrossRef]

40. Sugiyama, N., Tabuchi, Y., Numata, F., Uchida, Y., Horiuchi, T., Ishibashi, K., Ono, S., Obinata, M., and Furusawa, M. 1998. Establishment and characterization of tracheal epithelial cell lines, TM01 and TM02-3, from transgenic mice bearing temperature-sensitive simian virus 40 large T-antigen gene. Cell Struct. Funct. 23: 119-127. [Medline] [CrossRef]

41. Sullivan, C.S. and Pipas, J.M. 2002. T antigens of simian virus 40: molecular chaperones for viral replication and tumorigenesis. Microbiol. Mol. Biol. Rev. 66: 179-202. [Medline] [CrossRef]

42. Tabuchi, Y., Ohta, S., Arai, Y., Kawahara, M., Ishibashi, K., Sugiyama, N., Horiuchi, T., Furusawa, M., Obinata, M., Fuse, H., Takeguchi, N., and Asano, S. 2000. Establishment and characterization of a colonic epithelial cell line MCE301 from transgenic mice harboring temperature-sensitive simian virus 40 large T-antigen gene. Cell Struct. Funct. 25: 297-307. [Medline] [CrossRef]

43. Tabuchi, Y., Arai, Y., Ohta, S., Shioya, H., Takahashi, R., Ueda, M., Takeguchi, N., Asano, S., and Obinata, M. 2002. Development and characterization of conditionally immortalized gastric epithelial cell lines from transgenic rats harboring temperature-sensitive simian virus 40 large T-antigen gene. Cell Struct. Funct. 27: 71-79. [Medline] [CrossRef]

44. Tabuchi, Y., Doi, T., Takasaki, I., Takahashi, R., Ueda, M., Suzuki, Y., and Obinata, M. 2008. Establishment and functional characterization of a tracheal epithelial cell line RTEC11 from transgenic rats harboring temperature-sensitive simian virus 40 large T-antigen. Cell Biol. Int. 32: 13441352. [Medline] [CrossRef]

45. Tai, G., Hohenstein, P., and Davies, J.A. 2012. Making immortalized cell lines from embryonic mouse kidney. Methods Mol. Biol. 886: 165-171. [Medline] [CrossRef]

46. Taichman, L., Reilly, S., and Garant, P.R. 1979. In-vitro cultivation of human oral keratinocytes. Arch. Oral Biol. 24: 335-341. [Medline] [CrossRef]

47. Takahashi, R., Hirabayashi, M., Yanai, N., Obinata, M., and Ueda, M. 1999. Establishment of SV40-tsA58 transgenic rats as a source of conditionally immortalized cell lines. Exp. Anim. 48: 255-261. [Medline] [CrossRef]

48. Tavelin, S., Milovic, V., Ocklind, G., Olsson, S., and Artursson, P. 1999. A conditionally immortalized epithelial cell line for studies of intestinal drug transport. J. Pharmacol. Exp. Ther. 290: 1212-1221. [Medline]

49. Towbin, H., Staehelin, T., and Gordon, J. 1979. Electrophoretic transfer of proteins from polyacrylamide gels to nitrocellulose sheets: procedure and some applications. Proc. Natl. Acad. Sci. USA. 76: 4350-4354. [Medline] [CrossRef]

50. Wang, X., Pasolli, H.A., Williams, T., and Fuchs, E. 2008. AP-2 factors act in concert with Notch to orchestrate terminal differentiation in skin epidermis. J. Cell Biol. 183: 
37-48. [Medline] [CrossRef]

51. Watanabe, R., Wu, K., Paul, P., Marks, D.L., Kobayashi, T., Pittelkow, M.R., and Pagano, R.E. 1998. Up-regulation of glucosylceramide synthase expression and activity during human keratinocyte differentiation. J. Biol. Chem. 273: 9651-9655. [Medline] [CrossRef]

52. Whitehead, R.H. and Robinson, P.S. 2009. Establishment of conditionally immortalized epithelial cell lines from the intestinal tissue of adult normal and transgenic mice. Am. J. Physiol. Gastrointest. Liver Physiol. 296: G455-G460. [Medline] [CrossRef]

53. Wu, T., Jia, L., Du, R., Tao, X., Chen, J., and Cheng, B. 2011. Genome-wide analysis reveals the active roles of keratinocytes in oral mucosal adaptive immune response. Exp. Biol. Med. (Maywood). 236: 832-843. [Medline] [CrossRef]
54. Yanai, N., Satoh, T., Kyo, S., Abe, K., Suzuki, M., and Obinata, M. 1991. A tubule cell line established from transgenic mice harboring temperature-sensitive simian virus 40 large T-antigen gene. Jpn. J. Cancer Res. 82: 1344-1348. [Medline] [CrossRef]

55. Yanai, N. and Obinata, M. 1994. Apoptosis is induced at nonpermissive temperature by a transient increase in p53 in cell lines immortalized with temperature-sensitive SV40 large T-antigen gene. Exp. Cell Res. 211: 296-300. [Medline] [CrossRef]

56. Zhang, J., Zhi, H.Y., Ding, F., Luo, A.P., and Liu, Z.H. 2005. Transglutaminase 3 expression in C57BL/6J mouse embryo epidermis and the correlation with its differentiation. Cell Res. 15: 105-110. [Medline] [CrossRef] 